\section{Research Article}

(c) 2020 Fazil et.al.. This is an open access article licensed under the Creative Commons Attribution-NonCommercial 4.o International License (https://creativecommons.org/licenses/by-nc/4.o/)

\title{
Accommodating Minorities into Sri Lanka's Post-Civil War State System: Government Initiatives and Their Failure
}

\author{
Mansoor Mohamed Fazil ${ }^{\text {* }}$ \\ Mohamed Anifa Mohamed Fowsar ${ }^{1}$ \\ Vimalasiri Kamalasiri ${ }^{1}$ \\ Thaharadeen Fathima Sajeetha ${ }^{1}$ \\ Mohamed Bazeer Safna Sakki ${ }^{1}$ \\ ${ }^{1}$ Department of Political Science, \\ Faculty of Arts and Culture, \\ South Eastern University of Sri Lanka, \\ University Park, Oluvil, Sri Lanka \\ ${ }^{*}$ Corresponding Author
}

DOI: https://doi.org/10.36941/ajis-2020-0132

\begin{abstract}
Many observers view the defeat of the Liberation Tigers of Tamil Eelam (LTTE) in May 2009 as a significant turning point in the protracted ethnic conflict that was troubling Sri Lanka. The armed struggle and the consequences of war have encouraged the state and society to address the group rights of ethnic minorities and move forward towards state reconstitution. The Tamil minority and international community expect that the Government of Sri Lanka (GOSL) must introduce inclusive policies as a solution to the ethnic conflict. They believe the state should take measures to avoid another major contestation through the lessons learned from the civil war. The study is a qualitative analysis based on text analysis. In this backdrop, this paper examines the attempts made for the inclusion of minorities into the state system in post-civil war Sri Lanka, which would contribute to finding a resolution to the ethnic conflict. The study reveals that numerous attempts were made at various periods to introduce inclusive policies to achieve state reconstitution, but those initiatives failed to deliver sustainable peace. The study also explores problems pertaining to contemporary policy attempts.
\end{abstract}

Keywords: civil war, majority, militant, minority, social force, society, state

\section{Introduction}

Sri Lanka is well-known all over the world for the protracted ethnic conflict and civil war that lasted over three decades. It caused the deaths of about 100,000 persons, most of whom were members of minority communities. The violence also resulted in the forcible displacement of hundreds of thousands of people internally and to other countries (Nadeeka \& Rodney, 2010; Imthiyas \& Iqbal, 2011). Since 1948 when Ceylon as it was known then got its independence, there has been much debate in politics on the issue of transforming and reconstituting the state and society from its unitary character into one that reflects a more plural character. When Tamil minority political elites demanded regional 
autonomy for the Northern and Eastern provinces that required reconstituting the unitary nature of the country, a contestation began between the state and society (Kearny, 1967; Wilson, 1988, 2000; Orjuela, 2004; Manogaran, 2008; Uyangoda, 2012). Seven decades have passed by, but the state reconstitution project still remains a controversial subject in the Sri Lankan political arena.

By the mid-197os, the clamour of Tamil politicians for federalism intensified and a new demand arose for a separate Tamil state called "Tamil Eelam" that combined the Northern and Eastern provinces, which they claimed to be their traditional homeland. In the 1977 general elections, the Tamil United Liberation Front (TULF) won all seats in the Tamil areas on the platform of separatism (Global Investment Centre, 2010). Other groups, especially the LTTE, tried to establish an independent state by military means (Fazil, 2019; Fowsar, 2020). Over the years the conflict escalated in the northern and eastern regions of the island. Subsequently, it turned into a war between the Government and the main Tamil movement, the LTTE. The LTTE had gained the upper hand over the other Tamil militant groups (Fazil, 2019a, 2019b \& 2019c; Kamalasiri, 2020). This organization had set up an infrastructure so extensive and well supported with resources that it was able to endure and succeed in many battles against the superior military might of the Government. As a result of this protracted war, and the way it was brought to an end in May 2009, Sri Lanka became a subject of popular discourse and debate among scholars everywhere.

In fact, from the beginning of the twenty-first century, many militant social forces have faced challenges in different parts of the world. Several militant organizations have been proscribed as terrorist movements in recent times. In the case of the LTTE, it faced challenges not only from the state of Sri Lanka but also suffered several setbacks in the international arena; this situation eventually led to the destruction and defeat of the LTTE in 2009. Both national and international factors contributed to the defeat of the LTTE. Centralized leadership of Prabhakaran and inadequacies of his strategy, friction within the Tamil militant social force (LTTE), the defection of the political wing of the LTTE (Hashim, 2014), strong state leadership and security, and the inability of LTTE to fight hybrid warfare effectively, were the national factors that led to defeat. The assassination of ex-Prime Minister Rajiv Gandhi in India, the changes in international politics after the September 11 attacks in New York in 2001, declaration of the Global War on Terror (GWOT), and the China factor in global power balance were the international factors associated with the defeat of the LTTE (Fazil, 2019).

After this contextual change, many observers were of the view that the terrible costs and consequences of war would encourage the state and society to address the group rights of ethnic minorities and move forward towards state reconstitution to introduce inclusive policies (Marcelline \& Uyangoda, 2013). Contrary to this expectation, certain circumstances that led to controversy at the end of the war between the Sri Lankan state and the LTTE further complicated state-minority relations. Consequences of the 9/11 terrorist attack on the United States and its counter-response by launching the Global War on Terrorism were the key influential factors for the state's unexpected victory over the LTTE. Thus, the impact of the post-9/11 international agenda destroyed the formidable social force that contested the state for the formation of a separate state to safeguard the Tamil minority (Fazil, 2019c). This defeat has apparently weakened the Tamils and strengthened the state during the post-war period, hampering all kinds of attempts to find a fair resolution to the ethnic issues. In the process, the demand of the Tamil minority for inclusive policies was ignored by the state as it was now in a much stronger position.

This study examines the attempts made by the Tamil parties asking for inclusion of minorities into the state system as this would help to address their grievances in the post-war context. Importantly, post-civil war initiatives taken for inclusive policies during the Rajapaksa regime and Sirisena's Government are studied in this paper. The study also explores problems pertaining to contemporary policy attempts. Several attempts were made, such as the Lessons Learnt and Reconciliation Commission (LLRC), Government - Tamil National Alliance (TNA) talks, Parliamentary Select Committee (PSC) sittings, South African Initiatives, Regime Change and National Government in Power, $19^{\text {th }}$ Amendment and Announcement of New Constitution. 


\section{Research Method}

This study is based on the qualitative method that uses text analysis along with limited observation. In this section, the authors discuss the methodology and its relevance to Sri Lanka. The data for this research were collected using multiple methods, including an extensive literature survey to gather documents written on the post-independent state formation and state-minority contestations that occurred in the country, and further supplemented with a process of limited field observations and reflections. This two-step approach was followed for the qualitative data collection carried out during the period 2013 to 2017. Qualitative data were analyzed by adopting critical and interpretative approaches. Empirical materials and data were classified, weighed, and combined in these approaches. These processes were successfully followed in the current study. Thus, this paper reviews the new political trends that resulted after the end of the war, which provided opportunities to reconstitute the state based on the lessons learnt from the war, but were not utilized by the state.

\section{Results and Discussion}

This section reviews the findings of the study in respect of each post-civil war attempt made to find a solution to the protracted conflict in Sri Lanka.

\subsection{Lessons Learnt and Reconciliation Commission (LLRC)}

Following internal armed conflicts, several truth commissions have been established in various countries to investigate and record the violence that occurred during the conflict and to formulate recommendations to bring about reconciliation on the basis of devolution of power. There are some notable examples of truth commissions that functioned in East Timor, Guatemala, Rwanda and South Africa (International Justice Resource Center [IJRC], n.d) at different times. When we compare these with the Sri Lankan truth commission, we find that the outcome is entirely different here. In the aftermath of the civil war in Sri Lanka, the Lessons Learnt and Reconciliation Commission (LLRC) was appointed by the Government of Sri Lanka (GOSL) in May 2010 (Ratwatte, 2012).

Post-civil war LLRC and its mandate provided a new avenue to examine the issues pertaining to state reconstitution in Sri Lanka by exploring the following questions: Why did the Government of Sri Lanka appoint the LLRC at the end of the war? What changes were recommended pertaining to devolution of centralized power and state reconstitution to heal the wounds of war and promote reconciliation after the protracted ethnic conflict? To what extent have the LLRC's recommendations on the matter of state reconstitution been implemented in the last four years? The following section attempts to answer these questions.

The defeat of the LTTE did not bring the ethnic conflict to an end, as due to the political manoeuvrings of the Tamil Diaspora there has been consistent international pressure on Sri Lanka to work out some form of a political solution and show a willingness to investigate issues of humanitarian and human rights violations during the final stage of the war (Thiranagama, 2013). Several foreign countries, U.N. bodies, International and Local Non-Governmental Organizations, and civil society organizations have been applying heavy pressure upon the State of Sri Lanka in the following ways:

"The call for an investigation into the deadly conflict began when Secretary-General Ban Ki-Moon of the United Nations expressed his intention to appoint a panel of experts in March 2010. On May 31 2010, United Nations (U.N.) High Commissioner for Human Rights, Navi Pillay called on the Sri Lankan government to allow an international inquiry into the Government's offensive against the Tamil Tigers. Western governments, including the United States, also applied pressure on the Sri Lankan government to launch an impartial investigation into allegations of war crimes perpetrated by the state security forces and the LTTE. International Civil rights organizations, including Amnesty International and Human Rights Watch, joined the U.N. officials' calls for accountability into crimes committed in Sri Lanka. On May 17 2010, International Crisis Group (ICG) released a report entitled War Crimes in 
Sri Lanka, appealing for a concerted effort by the international community, led by the United Nations, to further investigate alleged war crimes by Sri Lankan security forces and the LTTE and prosecute those responsible" (United Nations Regional Information Centre for Western Europe [UNRICFWE], 2016).

The Government, however, stated it engaged in a "humanitarian rescue operation" with a policy of "zero civilian casualties" (U.N., 2011, p. ii). To appease the international community, Sri Lankan President Mahinda Rajapaksa appointed the Lessons Learnt and Reconciliation Commission (LLRC) on May 15, 2010 (LLRC, 2011) to investigate the failure of the Cease Fire Agreement (CFA) of 2002. The final report of the LLRC was submitted to the President on November 15, 2011, but it remained unpublished until December 16, 2011 (Fowsar, 2015). The commission also had to report on the sequence of events that occurred from the time the CFA was signed up to May 192009 and pointed out the lessons that should be learnt from them. The institutional, administrative and legislative areas were also looked into, in order to prevent any misunderstanding and to promote national unity and reconciliation among the diverse communities in future (LLRC, 2011; Ratwatte, 2012). According to the report, the commission also recommended the Government to deal with the issues of devolution. In this regard, "in Chapter 8, a sub-topic titled 'The Need for Devolution of Power', adopts a positive approach and dismisses the government stance of being unsure as to whether devolution is needed" (LLRC, 2011, as cited in Kelegama, 2015, p. 246). The LLRC clearly states that devolution is needed and there is no doubting it. Following is a brief account of the recommendations given in the LLRC report about the devolution of power.

A devolution based political settlement must address the ethnic and other serious problems that threaten democratic institutions. In order to ensure sustainable reconciliation, the commission wishes to underline the critical issues on the devolution process. Therefore, the commission recommends that the present opportunity should be utilized for both maximum possible devolution to the periphery at the grassroots level and power-sharing at the center. To this end, the Government must take the initiative to have a serious and structured dialogue with all political parties, including the minorities (LLRC, 2011, pp. 305-307).

The National Plan of Action (NPA) was released by the GOSL to implement the recommendations of the LLRC on July 262012 ("The LLRC", 2015, March 17). An action plan was formulated to address the need for devolution or state reconstitution as written in the recommendation no. of 9. 236, 237 as, "Take the initiative to arrange a serious and structured dialogue with all political parties, and those representing minorities, in particular, to develop consensus on devolution. The dialogue must take place at a high political level and with adequate technical back-stopping" (Government of Sri Lanka, 2015, p. 13). This plan was formulated during Mahinda Rajapaksa's term of office. However, more than three years later, the overall implementation status of the LLRC recommendations has been disappointing. Meanwhile, newly elected President Maithripala Sirisena and the national Government pledged to implement the recommendations of the LLRC. In this backdrop, the next section will examine Rajapaksa's other commitment to address the ethnic conflict by appointing a Parliamentary Select Committee to prepare a proposal to resolve this issue.

\subsection{Government-TNA Talks: A Stalemate Situation}

One of the negative aspects of Sri Lankan Politics in 2011 was the abortive attempt by the Government to find a political solution to the pressing problems of Tamils. The talks that commenced between the Government and the Tamil National Alliance (TNA), one year after Mahinda Rajapaksa was re-elected as president for a second term in office, did not make any progress. Although the TNA was able to win a majority of parliamentary seats in the North and East in 2010 and proved itself as a credible representative of the Tamils, President Rajapaksa showed no interest in initiating a dialogue with the TNA throughout the year 2010 (Marcelline \& Uyangoda, 2013, cited in Fazil, 2019a). Nevertheless, there was substantial international pressure being exerted on the Government to arrive at a political solution by engaging in dialogue with the TNA. Appearing to oblige, President Rajapaksa invited the TNA for 
talks that began in January 2011. The 14 meetings that are reported to have taken place between both parties in 2011 produced no tangible results. The TNA submitted two sets of political proposals to the Government in February and March, but received no response from the Government despite the fact there were seven meetings between January and August 2011. The TNA insisted on (a) devolution of police and land powers to the provincial councils with full implementation of the existing thirteenth amendment, (b) empowering provincial councils by transferring the list of concurrent powers to the provincial list of powers, and (c) re-merging of the northern and eastern provinces into a single unit of devolution. The Government's failure to respond to the proposal of the TNA can be construed as the rejection of the contents of the proposal. According to media reports, President Rajapaksa and his constituent partners in the United People's Freedom Alliance (UPFA) had expressed their unwillingness to transfer police and land powers to the provincial councils. Based on political analysis, President Rajapaksa had appeared inclined to dilute the 13th amendment by removing police and land powers from the provincial councils' list of powers. A proposal of this nature aimed at reducing the power of provincial councils would result in undermining the existing power-sharing framework integrated into the constitution.

The abortive outcomes of Government-TNA meetings can be attributed to this atmosphere of uncertainty. In 2011, the TNA requested the Government to provide a written response to the proposals it made in February 2011 as an initial measure to pave the way for further continuance of the bilateral talks. The meetings that had taken place in August 2011 were a showcase of conflicting ideas between both sides, and their respective approaches to talks too were divergent, and the result was that the differences sharpened. It is reported that the TNA leader expressed his disappointment over the measure of seriousness the Government was taking with regard to the talks while blaming the Government by stating that the talks were being used as a camouflage to create an impression locally and internationally that they were in a serious process of reconciliation whereas the real situation was contrary to this image (Marcelline \& Uyangoda, 2013).

One main element pertinent to the discussion above was the absence of the LTTE in the war front, and this had the effect of eliminating any sense of urgency in finding a solution to the ethnic conflict. This led to the nature of the relations between the Government and the ethnic minorities being altered significantly (Marcelline \& Uyangoda, 2013). After May 2009, the key factor in the ethnic conflict in Sri Lanka was not the relationship between the state and the LTTE, but the relationship between the state and the ethnic minorities.

It appeared that the Sri Lankan government was no longer prepared to wake up to the urgency of a political solution, negotiated settlement and regional autonomy that were a priority only because of the military capability of the LTTE and the resultant threat to the Sri Lankan state. With the military defeat of the LTTE, the threat posed to the state was removed and the armed struggle of the LTTE, which catapulted them into stardom as architects defining and shaping the relations between the state and ethnic minorities positively also disappeared. Therefore, the parameters and conditions after the war ended have been tailor-made in favour of the state. In this situation of altered political conditions with respect to ethnic relations, the necessity and urgency for negotiations and a political solution were hardly felt by the state as they were before. The UPFA government was evidently indifferent towards this with no practical initiative being taken. This apathy presents a risk of the re-emergence of violence if the situation persists.

\subsection{Parliamentary Select Committee (PSC)}

Later on, the GOSL insisted that power-sharing and devolution must be addressed by a Parliamentary Select Committee (PSC) (ICG, 2013, p. 21). It is necessary to highlight at this point that the TNA gradually assumed the position of the alternative Tamil social force in the post-LTTE period. After the release of the interim report of the LLRC, the state was pushed to find a way forward by implementing its recommendations. It was in this background that President Rajapaksa and R. Sampanthan, the TNA leader, met together on September 2, 2011, on which occasion the president suggested his ideas on a 
political solution. President Rajapaksa proposed at this meeting the idea of setting up a Parliamentary Select Committee (PSC), which will make the final decision on the political solution to be taken. Soon the proposal for a PSC led to further disagreements between Rajapaksa and Sampanthan when the latter suggested that a bilateral consensus between the Government and the TNA should be presented to the PSC. While the Government wanted to proceed with the PSC even before arriving at a consensus with the TNA on a political solution, the TNA insisted that without such a consensus, the entire PSC process would be another futile exercise as had been the case with many such committees and commissions in the past. The TNA's refusal to send its nominees to the PSC quickly developed into a major political row, even raising a likelihood of the discontinuation of bilateral talks.

After several months of suspension in the talks, the two sides agreed to meet on January 17, 18 and 19, 2012. However, the Government did not send its delegation to the meeting, indicating that the dialogue had reached a serious impasse. It became apparent in the controversy that the two sides had somewhat exclusivist ideas regarding the implementation of the PSC proposal. The Government stressed that a political solution to the majority-minority conflict in Sri Lanka should be found by way of "an inclusive process with the participation of all political parties, not just the TNA" (Sunday Leader, January 17 2012, as cited in Marcelline \& Uyangoda, 2013, pp. 320-321). The TNA, on the other hand, held the view that a consensus between the two sides was a necessary precondition for a successful outcome of the PSC process and that the Government should give priority to a basic understanding with the TNA, the elected representatives of the Tamil people, before summoning the PSC. Thus, the Government-TNA dialogue remained stalled, despite international pressure on both sides to resume the dialogue and work together for reconciliation and a political settlement.

The National Plan of Action (NPA) released by the Government in July 2012 to implement the LLRC recommendations emphasized the need to refer the matter of devolution to the PSC first to obtain its approval. Anyway, there was a deadlock in early 2012 when the Government refused to send its delegation to the meeting. The GOSL used this situation as a tactic to avoid taking up any position of its own and to prevent any expansion in the devolution. In this situation, South Africa stepped in and offered its support to the reconciliation process in Sri Lanka. This is discussed in the following section.

\subsection{South African Initiatives}

The South African Government participated in the first third-party initiative as a facilitator in post-war Sri Lanka. It was anticipated with optimism that the state reconstitution attempt would resolve the ethnic grievances of minorities. When South African President Jacob Zuma visited Sri Lanka for the Commonwealth Heads of Government Meeting (CHOGM) in 2013, President Rajapaksa had asked him whether his country could act as a third-party mediator (Ministry of Foreign Affairs [MOFA], 2014). The continuous dialogue in this matter by the former External Affairs Minister G.L. Peris with his counterpart Maite Nkoana-Mashabane, South African Minister of International Affairs and Cooperation, resulted in the involvement of South Africa as a mediator.

Following this development, Nimal Siripala de Silva, Leader of the House and Minister of Irrigation and Water Resources Management, led a delegation to South Africa and held discussions there on the $20^{\text {th }}$ and 21st of February 2014. The aim of this visit was for Sri Lanka to acquire an understanding of the South African experience in reconciliation by learning about it from the South African Truth and Reconciliation Commission.

Following the visit of the Sri Lankan government representatives to South Africa, a Tamil delegation led by R. Sampanthan, comprising TNA members and fellow parliamentarians M.A. Sumanthiran, Selvam Adaikkalanathan and Suresh Premachandran also paid a visit there (Tamil Guardian, 2014). Landing in South Africa on April og 2014, they were received by Geoff Doidhe, the South African High Commissioner for Sri Lanka. During their three day visit to South Africa to learn about post-conflict reconciliation, they met with Maite Nkoana-Mashabane, South Africa's Minister of the Department of International Relations and Cooperation (DIRCO) and Deputy Minister Ebrahim. 
The delegation also interacted with officials of DIRCO who shared with them their experiences on the truth and reconciliation process (Tamil Guardian, 2014).

South African President Zuma, in his speech in parliament in February 2014, stated that in response to the appeal of the Sri Lankan Government, he was assigning Cyril Ramaphosa as a special representative to Sri Lanka. In June 2014, the special representative arrived in Sri Lanka, making his commitment clear with regard to the peace-building role. South Africa's role in Sri Lanka was explained to all levels of the ruling party at the African National Congress (ANC) annual convention in April 2014 (Perera, 2014). In his first public comments on his role, the Deputy President of the ruling ANC, Ramaphosa said, "We are truly honoured to be chosen among many countries to go and make this type of contribution to the people of Sri Lanka. We have a wonderful story to tell, and it is this wonderful story that the Sri Lankans see." He also said, "As South Africans, we do not impose any solution on anyone around the world. All we ever do is to share our own experience and tell them how, through negotiation, through compromise, and through giving and taking, we were able to defeat the monster of Apartheid." He added, "We think we can share those experiences, but of course, in the end, it is up to the people of Sri Lanka to find their own peace" (Perera, 2014).

The peace and reconciliation initiatives of South Africa could be classified as a third-party contribution in Sri Lanka. Previously, India and Norway took part as mediators and promulgated ceasefires between the GOSL and the LTTE to promote reconciliation and peace in the country. As a result of the defeat of the LTTE, a ceasefire was no longer necessary. Nevertheless, the South African attempt was a hopeful initiative to bring reconciliation (The Sunday Times, 2014).

Ramaphosa and his team met the president, prominent representatives of the Government and Wickremesinghe, the Opposition Leader. Notably, other important discussions were held with the TNA, with leaders such as R. Sampanthan and Chief Minister, Justice C.V. Wigneswaran. During his visit to Jaffna, Ramaphosa talked with Maj. Gen. (Rtd) G.A. Chandrasiri, Northern Province Governor and Udaya Perera, Security Forces Commander ("The Great South", 2014, July 10). South African initiatives were an acceptable way to move towards the post-war reconciliation process, and it was expected that this might provide a true sharing between both nations. Nonetheless, the process had been criticized by some of the majority leaders and radical movements. The South African delegation's meeting with Northern Province Chief Minister, Wigneswaran brought forth a host of race-centred criticisms, even five years after the end of the war.

It was expected that there was an opportunity to find a resolution to the ethnic conflict by devolving powers to the minorities in the post-war scenario. Anyway, the inclusive mechanisms initiated by the GOSL failed as usual. However, Rajapaksa and his Government continued to apply various stratagems to centralize power, such as passing the $18^{\text {th }}$ amendment, the Divi Neguma Bill, and by conducting impeachment proceedings against the former Chief Justice of the country. These centralization activities are briefly examined below (Fazil, 2019).

A drastic change embodied in the form of the $18^{\text {th }}$ amendment to the 1978 Constitution came in the wake of the presidential and parliamentary elections. Its purpose was to allow a third presidential term for President Rajapaksa, who led the UPFA coalition regime. The enactment of the $18^{\text {th }}$ amendment constituted a crucial development in Sri Lanka's post-civil war state reconstitution process as it was in the direction of further centralization of state power in the office of the president and in the hands of the person who holds that office. A key feature of the $18^{\text {th }}$ amendment was the repeal of the $17^{\text {th }}$ amendment, which had provided for a constitutional mechanism known as the Constitutional Council, to check some powers of the Executive President, such as the power to make key public service appointments. The $18^{\text {th }}$ amendment also revised the powers of several important public service bodies such as the Public Service Commission, the National Police Commission and the Elections Commission, by which more power was transferred to the executive.

\section{5}

Regime Change and the National Government in Power

After the war victory in 2009, Rajapaksa was elected to a second term as president by majority votes in 
2010, and then his party won the parliamentary elections too. He was in an ideal situation to rehabilitate, reconstruct and develop the country. However, President Mahinda Rajapaksa focused on other things, and his family domination started expanding to cover the entire ruling system of the country. This inevitably led to an increase in corruption and soft-authoritarianism in his regime.

President Mahinda Rajapaksa lost the presidential election in January 2015 owing to his unpopularity over charges of corruption, oppression of the minorities, undemocratic ruling style, militarisation and centralization of state power, etc. "President Rajapaksa's former Minister Maithripala Sirisena secured a surprise win as the common opposition candidate on the promise of implementing a 10o-day program of constitutional and governance reforms, after which parliamentary elections would be held" (Welikala, 2015). During the oath-taking ceremony held at the Independence Square on January o9 2015, the newly elected president was sworn-in as the sixth Executive President of Sri Lanka before the Chief Justice. Ranil Wickremesinghe, leader of the United National Party (UNP), was sworn-in as Prime Minister before President Maithripala Sirisena (Adaderana, January 09 2015). In a historic turn of events, the main opposition political party stitched together a coalition government with others that comprised 11 cabinet ministerial, five state ministerial and ten deputy ministerial positions. Ministers were sworn-in before President Maithripala Sirisena and in the presence of Prime Minister Ranil Wickremesinghe ("The More the Merrier," March 23 2015). In August 2015, the $08^{\text {th }}$ General Elections were held, but no party got a majority in the parliament. Eventually, a national government was formed by a coalition of parties. Interestingly, the prominent Tamil party TNA secured the position of the opposition party in the parliament.

Looking back, national and international factors contributed to the defeat of the Rajapaksa regime. The United National Party (UNP), People's Liberation Front - Janatha Vimukthi Peramuna (JVP), Jathika Hela Urumaya (JHU), Sri Lanka Muslim Congress (SLMC), All Ceylon Makkal Congress (ACMC) and the Tamil parties contributed to this significant victory and change. The crucial role played by the Western countries also contributed to this change as they tried to counter the growing Chinese influence in Sri Lanka and South Asia. The other motivation for regime change was the growth in Buddhist nationalism, which triggered anti-Muslim riots and human rights violations against minorities in post-war Sri Lanka. The newly elected Government promised to eradicate corruption, address the root causes of conflict and find a lasting solution to it, and exercise good governance during its period of office.

At the January 08, 2015 election Rajapaksa gained the votes mainly from Sinhala Buddhists while Maithiripala Sirisena obtained the votes of both majority and minority communities. "But one could easily argue that Maithri's victory was mainly due to the minority votes" (Kalansooriya, January o9 2015). Minorities in large numbers favoured Maithripala and in doing so expressed their opinion of Mahinda Rajapaksa. The intention behind this voting pattern of the minorities was not the same as it was in the case of the Sinhalese. That is because most of the Sinhalese who voted for regime change wanted democracy, good governance and an end to corruption. They were truly fed up with the Rajapaksa dynasty and wanted change.

Where the ethnic minorities were concerned, they had specific hopes behind their decision, such as the Tamils in the badly affected post-war areas who were eager for a return to normalcy. They demanded freedom of speech and association and in general, the freedom to do as they pleased within legal boundaries. Of course, this could be a matter for further deliberation based on a radicalization point of view, but Northerners have certainly prayed for freedom from the clutches of the LTTE as well as from military authoritarianism (Kalansooriya, January 09 2015). Implicitly they demand freedom from majoritarian rule and reconstitution of the state. As Tamil political parties felt they could obtain a positive response to their traditional demand for a homeland within the unitary state system from the new Government, they were in favour of this regime. But, "Surprisingly, Tamil and Muslim parties that backed Maithripala Sirisena, thereby ensuring his electoral victory, did not insist or bargain for any commitment to devolution" (Uyangoda, October 17 2015).

The Muslims had different expectations about securing their own identity and culture. As the Rajapaksa government did not clamp down on the anti-Muslim drive of certain forces, or protect the 
Muslims during the riots, their support shifted to the common candidate. People naturally expect the Government to safeguard them from marauding religious extremist groups.

Western countries played a behind the scenes role in the dramatic regime change in Sri Lanka. The foreign policy of the Rajapaksa government leaned towards non-western countries such as China, Russia, Pakistan, Iran and India in the Asian region, which caused much concern to the United States (U.S.) and its allies. The West repeatedly requested the GOSL to conduct an impartial inquiry into war crimes allegations and maintain the rule of law, democracy, freedom of expression and good governance. Despite their earnest promptings, the GOSL was not willing to pay any attention to the western demands. There is a strong suspicion that the United States of America (USA) was behind the overthrow of the Rajapaksa regime ("More Evidence" February 21 2015).

The sudden emergence of Sirisena as a "common opposition candidate" was an orchestrated affair. Sirisena, the serving Health Minister declared himself as a candidate in the election. He was backed by the UNP, the opposition and other parties after Rajapaksa announced the election date on November 20 2014. The World Socialist Web Site (WSWS) detailed the involvement of Washington, which acted through former President Chandrika Kumaratunga and UNP Leader Ranil Wickremesinghe in this election. The Obama administration worked strongly against Rajapaksa's ties with Beijing to ensure that Sri Lanka is fully integrated into the U.S. "pivot to Asia" as this would assist the military build-up against China. More proof of Washington's hand in Rajapaksa's removal has now come to light ("More Evidence," February 21 2015).

India, the regional power, had been alarmed because of China's security and economic relations with the Rajapaksa government. The media and intelligence sources disclosed strong evidence that India was on board in the removal of Rajapaksa and his Government (Ratnayake, 2015).

On the one hand, the USA, United Kingdom (U.K.) and European Union (E.U.) maintained good relations with the new Government. Diplomatic relations continued without interruption, and cordial mutual visits by leaders increased in number, and economic ties were also in favour of Sri Lanka. Remarkably, the frenzy of U.S. sponsored resolutions calmed down to some extent (Kirubakaran, 2015). On the other hand, neighbouring India, blamed by the ex-President as being a country that favoured the regime change, has not received its reasonable dividend. India is not happy about the recent developments in Sri Lanka. "Regarding the ethnic conflict, they took a very lenient path, but that trick didn't work with the new government" (Kirubaharan, 2015). The new Government wished to maintain its relationship with India and China in an equal manner. Sri Lanka could not sideline China in its endeavour to achieve post-war economic development and this disappointed India. Anyway, India's foreign policy decision-makers were carefully observing silent diplomacy while Sri Lanka was watchful of its giant neighbour's next move.

However, the new Government was concerned with bringing about a return to normalcy, democracy and protection of basic human rights that will ultimately meet the expectations of its citizens. The biggest challenge to the coalition government was in managing these hopes of the people, by handling the conflicting political agendas of coalition members adroitly. Moreover, the president, after assuming power took initiatives to fulfil the people's social and economic needs as was promised during the election period. Some of the initiatives were, increasing the salaries of the public servants, addressing the pension issue and tackling the high cost of living by bringing down the prices of some essential items. The new Government also launched an anti-corruption drive by starting to investigate and identify those involved in bribery, corruption and misuse of power during the Rajapaksa regime.

\section{$3.619^{\text {th }}$ amendment}

The last three amendments to the constitution were significant in many ways. In 2001, the Seventeenth Amendment to the constitution was enacted during the period when Chandrika Bandaranaike was president, for the purpose of setting up an independent appointment mechanism. But it was replaced by the Eighteenth Amendment to the constitution in 2010 by the Rajapaksa government. Then in 2015, the 'Good Governance' coalition government introduced the Nineteenth Amendment. This 
amendment set high expectations in respect of further reform of politics and administration (Gunatilleke, 2019).

The presidential election manifesto of 2010 had given priority to state reconstitution while the 2015 manifesto had given up on the idea. Anyway, it was expected that Maithripala Sirisena's Government would move forward on the post-war agenda on government reconstitution and state reconstitution. But after he came to power, he focused only on the government reconstitution agenda mentioned in his policy manifesto. State reconstitution was not being addressed to meet the expectations of the minorities who voted in large numbers for his victory with high hopes of greater devolution of power as a solution to the ethnic conflict in the island.

Crucially, Sirisena gave special attention to the abolition of the Executive Presidential system and to electoral reform. He stated in his manifesto, "The new constitutional structure would essentially be an Executive allied with the parliament through the cabinet, unlike the present autocratic Executive Presidential System. Under this system, the president would be equal to all other citizens before the law" (Maithri, 2015, p. 14). Accordingly, he repealed the $18^{\text {th }}$ amendment to the constitution by enacting the $19^{\text {th }}$ amendment, which reduced the power of the executive president and the period of office, while increasing the power of the Prime Minister. The key changes made by this amendment can be seen in Chapter VII, Chapter VII A, and Chapter VIII of the Constitution (Senaratne, 2019). Welikala (2015) summarises the $19^{\text {th }}$ amendment as follows:

A number of long-overdue reforms have been introduced through the $19^{\text {th }}$ amendment. Significantly, the presidential term was reduced from six to five years while the two-term office limit has been restored. Although the president can call for another presidential election after four years in office during his first term, the parliament's term has also been reduced to 5 years. It is an acute condition that unless a two-thirds parliamentary majority approves, the president cannot dissolve parliament until the expiration of $4^{1 / 2}$ years of its term. By establishing more or less fixed presidential and parliamentary terms, these provisions restrict presidential discretion and at the same time strengthen the separation of powers. Presidential immunity from suit has been marginally reduced by extending the Supreme Court's right to make legal decisions and judgments on official acts of the president. The report of the urgent bill procedure is the brief of other provisions of the amendment. The amendment also restricts the number of cabinet ministers to thirty. If the first and second-largest parties represented in parliament come together to form a national government, the size of the cabinet could be enlarged through an act of parliament (Welikala, 2015).

Freedom of information has been added to the third chapter of the constitution by making it an enforceable legal right. In order to provide the institutional apparatus to facilitate the practice and promotion of the constitutional right to information, freedom of information legislation was proposed as part of the 10o-day program. The de-politicization framework that was set up with the constitutional council and the independent commissions has proved to be a powerful feature of the $19^{\text {th }}$ amendment (Welikala, 2015). The Constitutional Council is a body chaired by the Speaker and comprised of ten members. This body oversees and ensures the appointment of top public officials and commissions recognized under the constitution only with the recommendation of the council's members (Senaratne, 2019). These arrangements that existed in the $17^{\text {th }}$ amendment and suspended by the $18^{\text {th }}$ amendment were re-introduced in the $19^{\text {th }}$ amendment. Anyway, Maithripala Sirisena's regime could not dismantle the presidential system entirely as a result of a constitutional restriction, which calls for a referendum to make further changes. In any case, if the President and Prime Minister come from the same political party, this amendment will be weak and meaningless (Senaratne, 2019). Other than that, it is an excellent mechanism to ensure proper checks and balances.

\subsection{Announcement of the New Constitution}

The new regime's agenda for state reconstitution on the basis of devolution of power emerged from Sri Lanka's Prime Minister (PM) Ranil Wickremesinghe, who declared after assuming duty that his Government would implement the $13^{\text {th }}$ amendment to the country's constitution. Over a period of 
nearly 30 years, this amendment, which provided a measure of devolution of power to the Tamil minorities in the Northern and Eastern provinces, was never implemented fully (Wijesiriwardena, 2015, January 27). Not surprisingly, the promise made by the present PM has also not materialized so far, and its outcome was no different from the outcomes of the same promises made by previous leaders.

Remarkably, another historical policy document was released by the UNP-led coalition government on July 23 2015. "The manifesto indicates the policy of the UNP-led front for the next five years. Its five-point programs are economic growth, fighting corruption, ensuring freedom for all, promoting infrastructure investments and improving the education system" (Asian Mirror, July 23 2015). The third point of the document was "Ensuring Freedom for All," which meant "steps would be taken to introduce a new constitution. The United National Party said measures would be taken to grant maximum devolution of power to the provinces with everyone's consent under a singular state" (News 1st, July 23 2015). This standpoint of the new GOSL was in accordance with both the national commission (LLRC) and United Nations Human Rights Council (UNHRC) resolutions made during the post-war years, which urge the need to "reach a political settlement" to the ethnic conflict (LLRC, 2011; UNHRC, 2012).

The GOSL is making an attempt to draft a new constitution, as mentioned in their policy manifesto. The initiative for new constitutional drafting and minority expectation of state reconstitution has once again opened the space for debate on the sharing of state power between the majority and minorities (Smantha, 2016). President Maithripala Sirisena proposed a sub-committee of the cabinet under the Prime Minister, who will be in charge of preparing a "conceptual note" on constitutional changes that will be submitted for approval to the Cabinet of Ministers. In accordance with this proposal, the PM appointed a cabinet sub-committee on December 02 2015. The concept note was to review the essentiality and way forward to form a new constitution (Balachandran, December 03 2015). The cabinet sub-committee comprised representatives from the UNP, SLFP, SLMC, ACMC, JHU, and the Tamil Progressive Alliance (TPA). Prime Minister Ranil Wickremesinghe headed the cabinet sub-committee, which comprised 11 members, of whom o7 were Sinhalese, o2 were Tamils, and o2 were Muslims. They were Nimal Siripala de Silva, Lakshman Kiriella, Rauff Hakeem, Susil Premajayantha, Rishad Bathiudeen, Patali Champika Ranawaka, Wijeyadasa Rajapakshe, D.M. Swaminathan, Mano Ganesan and Malik Samarawickrama (Balachandran, December o3 2015). This committee was directed by the president to consult various political groups and representatives of public organizations first. The sub-committee then prepared a conceptual note and submitted it to the PM.

The cabinet approved the conceptual note prepared by the cabinet sub-committee on January o9 2016, around the time when President Sirisena completed his first year in office, PM Wickremesinghe placed the proposal in parliament. The framework was for forming a new constitution and converting the parliament into a "Constitutional Assembly," thus commencing the formal procedures to implement President Sirisena's policy document prepared for the election (Ramakrishnan, 2016). The PM spoke in the parliament on the occasion of his submission of the draft resolution saying "we will have the whole Parliament formulating the constitution unlike in the previous instances when constitutions were drafted outside of the Parliament" (Singh, 2016). After two months, on March o9, 2016, the parliament passed the proposal of the PM. "The Government boasted that the resolution was passed unanimously, but the process dragged on for two months amid infighting within the ruling elites. About two dozen parliamentarians aligned with Rajapaksa opposed the resolution unless it incorporated their demands" (De Silva, 2016).

A joint opposition in the parliament was formed by the UPFA with the alliance of Rajapaksa's followers from the SLFP. After the Government agreed to delete the preamble and wording referring to the abolition of the executive presidency and for a "constitutional resolution of the national issue", they backed the resolution to write a new constitution. "The preamble of the original resolution that talked of providing a constitutional resolution to the Tamil question had been removed" (Ramakrishnan, 2016, March 10). It was obvious that the GOSL was committed to resolving the minority Tamils' grievances. The ruling elites of the majoritarian community opposed and removed the 
preamble that favoured Tamils. It was a case of history repeating itself as with every resolution that attempted to meet the Tamils' demands in the post-independent era.

However, this time around there was genuine concern regarding the Tamil grievances as the Government expected to address them. President Sirisena supported the devolution of power to the provinces through the new constitution within a united Sri Lanka (Sing, 2016). Speaking on devolution of power he said that is the practice in developed nations and it is not good to centralize it. He also stated that devolving powers are effective in terms of democracy, independence, human rights and fundamental rights. President Sirisena, in his address to the Parliament on January 09, 2016, had observed, "We need a constitution that suits the needs of the $21^{\text {st }}$ century as that will ensure that all communities live in harmony." Likewise, on January 15 2016, Prime Minister Wickremesinghe noted, "We are ready to devolve power (to minority Tamils) and protect democracy. The Constitutional Assembly will discuss with all, including (Tamil-dominated) provincial councils to have a new constitution. We will do that in a transparent manner" (Singh, 2016).

Historically, this was the first time in post-independence Sri Lanka that the Tamil political parties and Tamil civil society movements showed eagerness to participate in new constitution-making. As the Government declared, the new constitution would provide a constitutional resolution to the ethnic conflict, and that would be a very positive development. It must be noted that the Tamils refused to participate in the constitution-making process in both 1972 and 1978 . The reason for boycotting the 1972 Constitution-making was because the Government of Sirimavo Bandaranaike refused the demand of the Tamils to amend the official language clause in the draft constitution. As the Tamils had elevated their demand to a separate Eelam instead of better representation within a united Sri Lanka Lanka, they boycotted the 1978 constitution-making as well (Singh, 2016).

Currently, the Tamil elites represented by the TNA are seeking a so-called political solution through internal self-determination within a united Sri Lanka. Mr. Sampanthan, the leader of TNA, has repeatedly declared the current opinion of his community, that the Sri Lankan Tamils have abandoned their fight for a separate state and the ethnic problem will be resolved through a united and indivisible Sri Lanka. He also decisively declared that the Tamil speaking minorities included Muslims too and that "the Tamil speaking people have historically inhabited the North and East of Sri Lanka and are entitled to have it as one unit of devolution" (Sanmugathas, 2016). The Muslims' opinion was stated by the SLMC General Secretary Hasen Ali on January 10 2016, which was that, "The Sri Lanka Muslim Congress (SLMC) will submit a proposal to the Constitutional Assembly for a unit of devolution for the Muslims of the North and East based on the founder leader of the party, M.H.M. Ashraff s demand. A unit of devolution encompassing the non-contiguous geographic areas of domicile of the Muslims of the two provinces, with power-sharing arrangements on par with the Tamil community, has been the SLMC's demand from the inception."

Mahinda Rajapaksa and his followers opposed to making any meaningful concessions to the Tamils. His speeches have indicated that he is against devolving the crucial land and police powers to the Provincial Councils. The "joint opposition" is manifesting increased Sinhala chauvinist sentiments and accuses the Government of dividing the country by trying to hand over more powers to provincial councils (De Silva, 2016). All these issues pressurized the President and PM into agreeing to modify the resolution accordingly, gaining groundbreaking support to pass the bill. On March o9 2016, without calling for a vote, the Sri Lankan Parliament unanimously approved to change the parliament into a Constitutional Assembly (C.A.) to draft a new constitution for the country.

"WHEREAS there is broad agreement among the people of Sri Lanka that it is necessary to enact a constitution for Sri Lanka - this parliament resolves that there shall be a committee which shall have the powers of a committee of the whole parliament consisting of all Members of Parliament (M.P.s), to deliberate and seek the views and advice of the people, on a constitution for Sri Lanka, and preparing a draft of a constitution bill for the consideration of parliament in the exercise of its powers under Article 75 of the Constitution" (Parliament, 2016; ColomboPage, March 09 2016).

Welikala (2016) explains the nature of the C.A. and its activities in his scholarly work as follows C.A. will act as a separate institution, but it will comprise all the Members of Parliament (MPs). This 
mechanism is based on inclusivity and flexibility. Thus, all M.P.s can have a vital role to play in the C.A. on constitution-making process. At the same time, the C.A. could avoid the rigidity of parliamentary procedure and standing orders. Prime Minister chaired a steering committee with all parliamentary party leaders and other M.P.s, and the same committee directed the C.A. The CA has a number of subcommittees headed by senior M.P.s and reported on fundamental rights, the judiciary, public finance, the public service, law and order, and centre-periphery relations. The steering committee dealt with matters on electoral reform, devolution, and the central executive directly. Both the steering committee and sub-committees learnt their assigned responsibilities by considering the opinions and evidence of experts and civil society. The sub-committees submitted reports at the end of July 2016.

On December 29 2015, 24 members were appointed to the Public Representations Committee on Constitutional Reforms (PRCCR) by the Prime Minister. This committee was comprised of academics, lawyers, civil society representatives and political party representatives, who were expected to gather public opinion on the formation of a new constitution. The PRCCR worked to collect public opinion at the grassroots level from January 18 to February 292016 (Singh, 2016). This committee submitted its final report of 333 pages to the Government and released it to the public as well. According to their records, over 2500 people/organizations participated and shared their opinions orally and in writing. A further 800 opinions were shared via e-mail, 150 via fax messages and 700 by post or by hand delivery (Report on Public Representations on Constitutional Reforms, May 2016).

The work on the new constitutional draft was carried out by the steering committees. News media reports highlighted that PM "Ranil Wickremesinghe planned to present the draft constitution bill by the end of 2016, according to Lal Wijenayake, Chairman of the Public Representations Committee on Constitutional Reforms" (Ramakrishnan, June 03 2016; Eyesrilanka, June 03 2016). He further clarified that various subjects spelt out by the steering committee were dealt with by six sub-committees. On completion of work by each of the subcommittees, their findings would be submitted to the steering committee. In addition to that, the steering committee would report to the C.A. with the draft proposal of the new constitution (Ramakrishnan, June 02 2016; Eyesrilanka, June 03 2016).

Finally, the expert panel of the Steering Committee on the constitutional draft released its second report on January 11 2019. This latest report or draft clearly mandated that it is a federal constitutional solution and included most of the aspects of federalism. Some of the prominent political elites of the Sinhala majority reacted to this by starting to criticize the draft and condemn its contents openly. Thus, this study predicted that the present draft would manifest the following shortcomings, such as establishing a strong unitary state with highly centralized and inefficient bureaucracy; the possibility of regrouping of Tamil militant social forces and the consequent need for strengthening the state security; lack of elites' consensus, electoral purpose and influence of majority community; unstable Government; radical hardline forces; and problems of regional minorities in the North and East continuing as before.

Joint opposition comprising Rajapaksa and his team formed a new political party called the Sri Lanka Podujana Peramuna (SLPP) and worked hard to return to power. He resorted to nationalism to obtain the massive support of the majority and campaigned that the constitutional reforms posed a threat to the unity of the country. The result worked out in favour of the SLPP in the local government elections that were conducted under the new electoral system in February 2018. Then, President Sirisena decided to support the joint opposition and passed a 'no confidence' motion against Ranil Wickremesinghe (Rajasingham, 2019).

Because of this, debates and internal conflicts arose within the coalition government. President and Prime Minister espoused different ideas on the same political issues. The disagreements gradually increased, and both leaders were not able to work together. The president suddenly appointed Mahinda Rajapaksa as the Prime Minister on October 202018 (Senaratne, 2019). It was very clearly unconstitutional and illegal. Thus, the UNP challenged this appointment through the court. Senaratne (2019) notes that the Court of Appeal issued an interim order on this appointment. Later, the Supreme Court declared that the president had acted unconstitutionally in issuing such a proclamation. The president was thereby compelled to re-appoint Wickremesinghe as Prime Minister. 
Following this, the SLPP chose Gotabaya Rajapaksa, Ex-Defense Secretary as its candidate for the presidential election in 2019. He was always opposed to constitutional reform as a means of conflict resolution. He believed that economic development would serve as a better solution to the conflict rather than constitutional reform (Rajasingham, 2019). Gotabaya Rajapaksa won the presidential election in November 2019 (Lewis, 2020), following which Mahinda Rajapaksa was again appointed as the Prime Minister of the country.

Not too long after the presidential election, Sri Lanka was facing a pandemic situation due to the Covid-19 disease like in so many other countries across the world. Government's attention has now turned to face this problem rather than working on accommodating minorities into the state system. Anyway, the TNA met with the Prime Minister after nine years on May 042020 ("TNA meets PM," May 04 2020). As TNA boycotted negotiations with the ruling party in 2011, all talks ended then. But at this meeting, TNA expressed its willingness to cooperate with the Government in fighting the spread of the Covid-19 disease. The TNA brought up many issues such as handling the Covid-19 pandemic, release of the political prisoners, livelihood issues of Tamil minorities during the Covid-19 lockdown period, new constitution for resolving Tamil minority's problems, and general elections, etc. Further, a statement signed by the four constituent parties of TNA was handed over to the Prime Minister ("TNA meets PM," May 04 2020).

These incidents convey a clear message to the people that a sustainable resolution to the conflict through accommodating the minorities will take a long time. Ongoing contestations and the forthcoming general elections could determine the level of accommodation the minorities can expect within the state system.

\section{Conclusion}

This paper analyzed the recent political developments in post-civil war Sri Lanka. As the argument of this study shows, the ending of the civil war in Sri Lanka does not appear to have delivered either the environment or political motivation to introduce inclusive policies to address the ethnic conflict through dialogue and consensus. Also, many local and international observers assumed that the defeat of the LTTE and the lessons learned from the destructive civil war would impress on the Government the need to accommodate minorities into the state system by means of inclusive policies. Unfortunately, this approach has been abandoned by the Sri Lankan government because it found itself in a dominant position after the defeat of the LTTE. In this environment, most of the important ideas and proposals discussed above were not given a chance to bring peace to the country. These failed attempts also indicate that any proposed solutions have to be considered within a system of centralized state power. Most of the minority political parties that had formed coalitions with the Rajapaksa regime had also agreed to the centralization of power and the unitary state concept except the mainstream Tamil political party, the TNA. The Government's only initiative after forming the new parliament in 2015 was to appoint a "Constitutional Council" and get its experts to prepare and release the draft of a new constitution. But this process also remains stillborn without any positive outcome. Therefore, the present study suggests that Sinhala, Tamil and Muslim political elites should focus on an inclusive approach that would give equal consideration to all of the ethnic communities living in the country. This is absolutely essential to ensure a peaceful and prosperous Sri Lanka in which all communities can live together in harmony.

\section{References}

Adaderana. (2015, January 9). Maithripala Sirisena sworn-in as President, Ranil new Prime Minister. Retrieved from http://www.adaderana.lk/news/29355/maithripala-sirisena-sworn-in-as-president-ranil-new-primeminister.

Asian Mirror. (2015, July 23). United national front five point plan released (Full document). Retrieved from http://www.asianmirror.lk/news/item/10203-united-national-front-election-manifesto-released 
Balachandran, P.K. (2015, December 3). Two Tamils in Lankan Cabinet Panel to draft new constitution. The New Indian Express. Retrieved from http://www.newindianexpress.com/world/Two-Tamils-In-Lankan-CabinetPanel-To-Draft-New-Constitution/2015/12/o3/article3159278.ece?

ColomboPage. (2016, March 9). Sri Lankan parliament resolves to appoint a constitutional assembly. Retrieved from http://www.colombopage.com/archive_16A/Maro9_1457544668CH.php

De Silva, R. (2016, March 21). Sri Lankan parliament to draft new constitution to shore up capitalist rule. World Socialist Web Site (WSWS). Retrieved from https://www.wsws.org/en/articles/2016/03/21/sril-m21.html

Eyesrilanka. (2016, June 3). Govt to present draft constitution by year end. Retrieved from http://www.eyesrilanka.com/2016/o6/o3/govt-to-present-draft-constitution-by-year-end/

Fazil, M. M. (2019a). A bibliographic survey on state-minority contestations in post-colonial sri lanka. Journal of Politics and Law, 12(1), 48. Retrieved from http://www.ccsenet.org/journal/index.php/jpl/article/view/o/3866o

Fazil, M. M. (2019b). Migdal's Theory of the State-in-Society in the Context of Sri Lanka: A Critical Review. Academic Journal of Interdisciplinary Studies, 8(3), 292. Retrieved from http://www.richtmann.org/journal/index.php /ajis/article/view/10584

Fazil, M. M. (2019c). State-Minority Contestations in Post-colonial Sri Lanka. Journal of Educational and Social Research, 9(4), 157. Retrieved from https://www.mcser.org/journal/index.php/jesr/article/view/10542/10171

Fazil, M.M., Fowsar, M.A.M., Sakki, M.B.S., Sajeetha, T.F., \& Kamalasiri, V. (2020). State Reluctance towards Inclusive Policies in Post-Civil War Sri Lanka, Journal of Politics and Law 13 (3), 109-121. https://doi.org/10.5539/jpl.v13n3p109

Fowsar, M.A.M. (2015). Politics of Reconciliation in Post-war Sri Lanka: A Critical Study on the Report of Lessons Learnt and Reconciliation Commission. Book of Abstract, South Eastern University Arts Research Session, Faculty of Arts and Culture, South Eastern University of Sri Lanka, Oluvil, Sri Lanka.

Fowsar, M.A.M. (2020). Third-Party Mediation in Sri Lanka's Peace Attempts: A Study on the Role of Norwegian Mediation. Journal of Politics and Law, 13(3): 30-37. https://doi.org/10.5539/jpl.v13n3p3o

Global Investment Centre. (2010). Sri Lanka country study guide. Vol. I strategic information and developments. USA: Washington.

Government of Sri Lanka [GOSL]. (2015). National plan of action to implement the recommendations of the LLRC. Retrieved from http://www.priu.gov.lk/news_update/Current_Affairs/ca201207/National\%2oPlan\%20of \%2oAction\%20_\%2oLLRC.pdf

Hashim, A.S. (2014). When counterinsurgency wins: Sri Lanka's defeat of the Tamil Tigers, New Delhi: Foundation. Imthiyas, A.R.M., \& Iqbal, M.C.M. (2011). The displaced Northern Muslims of Sri Lanka: Special Problems and their Future. Journal of Asian and African Studies, 46(4), 376.

International Crisis Group [ICG].(2013). Impeachment of the Sri Lankan Chief Justice. Retrieved from https://www.crisisgroup.org/asia/south-asia/sri-lanka/impeachment-sri-lankan-chief-justice

Kamalasiri, V., Fowsar, M.A.M., \& Fazil, M.M. (2020). Disarmament, Demobilisation and Reintegration of Armed Groups in Post-war Sri Lanka: A Study based on Koralaipattu South Divisional Secretariat Division in Eastern Sri Lanka. Journal of Politics and Law, 13(3): 236-247. https://doi.org/10.5539/jpl.v13n3p236

Kearney, R.N. (1967). Communalism and language in the politics of Ceylon. Durham, USA: Duke University Press.

Kelegama, T. (2015). Impossible devolution? The failure of power-sharing attempts in Sri Lanka. Strategic Analysis, 39, 237-253. 10.1080/09700161.2015.1022315

Kirubaharan, S.V. (2015). International investigation on Sri Lanka should continue!. Retrieved from https://www.colombotelegraph.com/index.php/international-investigation-on-sri-lanka-should-continue/

Kalansooriya, R. (2015, January o9). Managing expectations. Retrieved from https://www.colombotelegraph.com/index.php/managing-expectations/

Lessons Learnt and Reconciliation Commission [LLRC]. (2011). Report of the commission of inquiry on lessons learnt and reconciliation. Retrieved from http://slembassyusa.org/downloads/LLRC-REPORT.pdf

Lewis, D.G. (2020) Sri Lanka's Schmittian peace: Sovereignty, enmity and illiberal order. Conflict, Security \& Development, 20(1), 15-37, DOI: 10.1080/14678802.2019.1705067

Maithri, S. (2015). Manifesto: A compassionate Maithri governance a stable country, New Democratic Front. (P. 14). Retrieved from http://asianmirror.lk/media/Manifesto_English.pdf

Manogaran, A.K. (20o8). Sri Lanka: Ethnic conflict and peace initiation. Chennai, India: The Parker.

Marceline, S., \& Uyangoda. J. (2013). Post-civil Sri Lanka: Dilemmas of state reform. In J. Uyangoda (Ed.), State reform in Sri Lanka: Issues, directions and perspectives. Colombo, Sri Lanka: Social Scientists' Association.

Ministry of Foreign Affairs [MOFA]. (2014). Foreign Minister Samaraweera meets Prince Zeid. Retrieved from http://www.mfa.gov.lk/index.php/en/media/media-releases/unhrc2015/6201-foreign-minister-zeid

More evidence of U.S. involvement in Sri Lankan regime-change. (2015, February 21). Retrieved from http://www.ft.lk/2015/o2/21/more-evidence-of-us-involvement-in-sri-lankan-regime-change/. 
Nadeeka, A., \& Rodney, A. (2010). Post-war opportunities for peace in Sri Lanka: An Ongoing Challenge? Global Change, Peace \& Security, 22(3).

Newsist.(2015, July 23). United National Front for Good Governance election policy manifesto unveiled. Retrieved from http://newsfirst.lk/english/2015/o7/united-national-front-for-good-governance-election-policymanifesto-unveiled/104831

Nineteenth amendment to the constitution - from start to finish. ConstitutionNet.org. Retrieved from http://www.constitutionnet.org/news/sri-lanka-nineteenth-amendment-constitution-start-finish

Orjuela, C. (2004). Civil society in civil war: Peace Work and Identity Politics in Sri Lanka. Goteborg, Sweden: Goteborg University

Parliament. (2016). Resolution for the appointment of the constitutional assembly. Retrieved from https://www.parliament.lk/files/documents_news/ca-motion/motion-en.pdf

Perera, A. (2014). A new phase of mediation to get from post-war to post-conflict Sri Lanka. Groundviews. Retrieved from http://groundviews.org/2014/05/05/a-new-phase-of-mediation-to-get-from-post-war-to-post-conflictsri-lanka/

Rajasingham, S. (2019). Federal or unitary? The power-sharing debate in Sri Lanka, The Round Table, 108(6), 653665. DOI: 10.1080/00358533.2019.1688064

Ramakrishnan, (2016, June 3). Ranil aims to present draft constitution by year-end. Retrieved from http://www.thehindu.com/news/international/ranil-for-draft-constitution-bill-by-yearend-panelchief/article8682419.ece

Ramakrishnan, T. (2016). Sri Lanka to convert its parliament to constitutional assembly next year. The Hindu. Retrieved from http://www.thehindu.com/news/international/wickremesinghe-to-move-motion-onconstitutional-assembly/article80oo797.ece

Ratnayake, K. (2015). Evidence of India's involvement in regime change in Sri Lanka. Retrieved from http://dbsjeyaraj.com/dbsj/archives/3785o

Ratwatte, C. (2012). Darusman, LLRC, petrie conundrum and the trial by media. Retrieved from https://www.colombotelegraph.com/index.php/darusman-llrc-petrie-conundrum-and-the-trial-by-media/

Report on Public Representations on Constitutional Reforms. (2016, May). Public representations committee on constitutional reform. Retrieved from http://constitutionnet.org/sites/default/files/sri_lanka_prc_reportenglish-final.pdf

Sanmugthas, P. (2016). Sampanthan calls for devolution of powers \& human rights accountability. Colombotelegraph. Retrieved from https://www.colombotelegraph.com/index.php/sampanthan-calls-fordevolution-of-powers-human-rights-accountability/

Senaratne, K. (2019). The executive and the constitutional reforms process in Sri Lanka. The Round Table, 108(6), 625-638. DOI: 10.1080/00358533.2019.1688500

Singh, S.B. (2016). Sri Lanka: Re-drafting for resolution - analysis. Eurasia Review. Retrieved from http://www.eurasiareview.com/28032016-sri-lanka-re-drafting-for-resolution-analysis/

Smantha, M. (2016). Sri Lanka's efforts at drafting a new constitution: Is Consensus Possible? Indian Council of World Affairs (ICWA). Retrieved from www.icwa.in/pdfs/VP/.../SriLankaEffortsDraftingNewConstitutionVP15022016.pdf

Tamil Guardian. (2014). Enter South Africa?. Retrieved from http://www.tamilguardian.com/article.asp?articleid=10689

The great South African secret. (2014, July 10). Retrieved from http://www.ft.lk/article/320294/The-great-SouthAfrican-secret

The LLRC: What lessons have we learnt about reconciliation?. (2015, March 17). Retrieved from http://www.ft.lk/article/39746o/The-LLRC--What-lessons-have-we-learnt-about-reconciliation-

The more the merrier for Maithri-Ranil nexus!. (2015, March 23). Retrieved from http://www.ft.lk/2015/03/23/themore-the-merrier-for-maithri-ranil-nexus/

The Sunday Times. (2014). South Africa mediation offers way out for govt. Retrieved from http://www.sundaytimes.lk/140420/columns/south-africa-mediation-offers-way-out-for-govt-93065.html

Thiranagama, S. (2013). Claiming the state: Postwar reconciliation in Sri Lanka. Humanity. Retrieved from http://humanityjournal.org/wp-content/uploads/2014/o6/4.1-Claiming-the-State.pdf

TNA atends PM meeting, insists it cannot be a substitute for P'ment. (2010, May 4). Retrieved from http://www.ft.lk/breaking_news/TNA-attends-PM-meeting-insists-it-cannot-be-a-substitute-for-Pment/10526-699692

United Nations [U.N.]. (2011). Report of the Secretary General's Panel of Experts on Accountability in Sri Lanka. Retrieved from http://www.un.org/News/dh/infocus/Sri_Lanka/POE_Report_Full.pdf.

United Nations Human Rights Council [UNHRC]. (2012). Promoting reconciliation and accountability in Sri Lanka. Retrieved from http://ap.ohchr.org/documents/dpage_e.aspx?si=A/HRC/RES/19/2 
United Nations Regional Information Centre for Western Europe (UNRICFWE). (2016). Human Rights bodies to decide on full international inquiry. Retrieved from http://www.unric.org/en/sri-lanka/27122-human-rightsbodies-to-decide-on-full-international-inquiry

Uyangoda, J. (2012). The state in post-colonial Sri Lanka: Trajectories of change. In D. Kjosavix and P. Vedeld (Eds.), The political economy of environment and development in a globalized world: Exploring the frontiers, (pp. 345-73). Essays in honour of Nadarajah Shanmugaratnam. Colombo, Sri Lanka: Social Scientists' Association.

Uyangoda, J. (2015, October 17). For a fresh beginning in Sri Lanka. Retrieved from http://www.thehindu.com/opinion/lead/lead-article-for-a-fresh-beginning-in-sri-lanka/article6772536.ece

Welikala, A. (2015). Sri Lanka's Long Constitutional Moment. The Round Table. The Commonwealth Journal of International Affairs, 104(5), 551-562.

Welikala, A. (2015, May 26). Sri Lanka: The nineteenth amendment to the constitution from start to finish. Retrieved from http://constitutionnet.org/news/sri-lanka-nineteenth-amendment-constitution-start-finish

Welikala, A. (2016, July 7). Sri Lanka's search for constitutional consensus amid social and political divisions. Retrieved from http://www.constitutionnet.org/news/sri-lankas-search-constitutional-consensus-amidsocial-and-political-divisions

Wijesiriwardena, P. (2015, January 27). Sri Lankan government promises "devolution pact" to woo Tamil elite. Retrieved from https://www.wsws.org/en/articles/2015/01/27/sril-j27.html

Willson, A.J. (200o). Sri Lankan Tamil nationalism: Its origins and development in the 19th and 20 th centuries. London: Penguin.

Wilson, A.J. (1988). The break-up of Sri Lanka: The Sinhalese-Tamil conflict. Hyderabad, India: Orient Longman. 